\title{
PERANCANGAN ALAT BANTU KERJA BERDASARKAN ANALISIS ERGONOMI POSTUR KERJA DAN KELUHAN BIOMEKANIK TENAGA MEKANIK MOTOR DI SEBUAH BENGKEL MOTOR DI TANGERANG
}

\author{
I Wayan Sukania \\ Program Studi Teknik Industri, Fakultas Teknik Universitas Tarumanagara \\ e-mail:wayans@ft.untar.ac.id
}

\begin{abstract}
ABSTRAK
Setiap pekerjaan yang dilakukan oleh manusia hendaknya dalam kondisi nyaman, aman, efektif dan produktif dan selamat. Pekerjaan di sebuah bengkel service motor merupakan pekerjaan fisik dan mental. Di dalam menjalankan tugasnya, tenaga mekanik mengambil berbagai postur kerja, karena sarana bantu kerja di tempat kerja kurang memadai, maka tenaga mekanik memaksakan tubuhnya untuk mengambil postur yang tidak ergonomis. Postur tidak ergonomis mengakibatkan keluhan pada otot rangka dan bila dilaksanakan dalam jangka waktu lama mengakibatkan munculnya penyakit akibat kerja yang disebut MSD (Musculoskeletal Dissorder). Postur kerja tenaga mekanik selama melaksanakan dianalisis menggunakan Metode Rapid Entire Body Assessment (REBA) sehingga dapat memberikan rekomendasi postur yang lebih aman dan nyaman. Dari sisi para mekanik keluhan biomekanik terbanyak terjadi pada bagian tubuh seperti pinggang, leher atas, lutut dan bahu kanan yang disebabkan postur yang tidak ergonomis, bahkan skor REBA mencapai angka 12 yang berarti sangat berisiko. Melalui analisis keluhan biomekanik, penyebab, harapan dan solusi diperoleh daftar kebutuhan untuk perancangan alat bantu kerja. Konsep alat bantu angkat motor yang dihasilkan yaitu dengan disain alas tempat meletakkan motor bidang persegi panjang. Konstruksi rangka penggerak berupa rangka silang. Tenaga penggerak menggunakan motor listrik yang menggerakkan poros berulir dan mekanisme reduksi putaran.
\end{abstract}

Kata kunci: NBM, kebutuhan, ergonomi, spesifikasi alat, REBA.

\section{ABSTRACT}

Every work carried out by humans should be in a comfortable, safe, effective and productive and safe condition. Work in a motorbike repair shop is physical and mental work. In carrying out their duties, mechanical workers take various work postures, because the means of working aids at work are inadequate, so the mechanical forces force their bodies to take postures that are not ergonomic. Ergonomic postures cause complaints on skeletal muscle and if implemented for a long time result in the emergence of an occupational disease called MSD (Musculoskeletal Dissorder). The mechanical work posture during the implementation was analyzed using the Rapid Entire Body Assessment (REBA) Method so as to provide a safer and more comfortable posture recommendation. From the mechanical side, the most biomechanical complaints occur in parts of the body such as the waist, upper neck, knees and right shoulder caused by an un ergonomic posture, even the REBA score reaches 12 which means it is very risky. Through the analysis of biomechanical complaints, causes, expectations and solutions obtained a list of needs for the design of work aids. The concept of motor lifting aids produced is the design of the base on which to place the rectangular field motor. The drive frame construction is in the form of a cross frame. The driving force uses an electric motor that moves the threaded shaft and rotation reduction mechanism.

Keywords: NBM, needs, ergonomics, tool specifications, REBA.

\section{PENDAHULUAN}

Berdasarkan pengamatan di berbagai bengkel servise motor, diketahui bahwa tenaga mekanik memegang peranan yang sangat penting. Tenaga mekanik atau sering disebut dengan montir dapat menjalankan perannya karena dibantu oleh alat bantu dan sarana kerja. Ada perbedaan suasana dan sarana kerja yang cukup mencolok antara bengkel sederhana dengan bengkel resmi merk perusahaan tertentu [1]. Perbedaan sarana kerja menyebabkan beban kerja dan postur kerja yang dialami oleh tenaga mekanik juga 


\section{Wayan Sukania}

berbeda. Beban kerja berbeda dan postur kerja berbeda tentu mengakibatkan keluhan biomekanik yang berbeda pula.

Pekerjaan di bengkel motor merupakan salah satu pekerjaan yang mengandalkan peran tenaga mekanik ketimbang tenaga mesin. Pekerjaan tenaga mekanik termasuk pekerjaan yang didominasi oleh pekerjaan fisik karena memerlukan pengerahan tenaga fisik yang cukup besar. Pengerahan tenaga boleh jadi lebih besar dari yang seharusnya apabila dilakukan dengan cara yang kurang tepat, tanpa sarana yang memadai. Oleh karenanya mereka berisiko mengalami keluhan otot rangka. Keluhan dapat diperparah apabila postur kerja tenaga mekanik tidak ergonomis. Di bengkel motor sederhana yang biasa terdapat di pinggir jalan besar umumnya tidak memiliki sarana service motor yang memadai. Hasil dari kunjungan dan pengamatan terhadap beberapa bengkel motor diketahui bahwa mereka tidak memiliki sarana yang lengkap dalam upaya menangani berbagai pekerjaan perbaikan maupun penggantian komponen motor. Semua motor dan hampir semua jenis penanganan motor ditangani di atas lantai bengkel. Bengkel hanya punya sarana bantu kerja yang minimum, padahal harga sarana tersebut tidak terlalu mahal dan dapat mempercepat proses servis motor. Namun ada sebuah bengkel motor yang sebelumnya sudah menggunakan alat bantu angkat motor (motorcycle lift), namun akhirnya dibongkar dengan alasan mengganggu gerakan selama melaksanakan pekerjaan. Luas ruangan bengkel memang sempit. Tanpa alat bantu yang memadai maka mengakibatkan tenaga mekanik motor dalam melaksanakan pekerjaannya terpaksa mengambil postur kerja tidak nyaman, yaitu antara lain berjongkok, menjangkau, memutar badan, menunduk dan mengerahkan tenaga berlebihan. Pekerjaan yang mengandalkan tenaga fisik dapat mengakibatkan gangguan muskuloskeletal. Apabila aktivitas fisik berlebihan dilakukan terus menerus, dapat berdampak negatif pekerja, seperti mengalami nyeri di bagian tubuh tertentu, mengalami gangguan otot atau bahkan merubah postur tubuh [2]. Apabila otot menerima beban statis secara berulang dan dalam waktu yang lama, maka akan dapat menyebabkan keluhan berupa kerusakan pada sendi, ligamen dan tendon [3]. Diketahui bahwa postur kerja merupakan salah satu penyebab terjadinya keluhan otot rangka atau Musculoskeletal Disorder (MSD) [4].

Oleh karena itu sangat perlu dilakukan penyelidikan untuk mengetahui postur yang mana saja yang berisiko sehingga dapat dilakukan tindakan perbaikan postur kerja. Analisis postur kerja dengan metode REBA dan RULA serta metode lainnya sangat perlu dilakukan untuk mengetahui resiko postur kerja yang dilakukan oleh tenaga mekanik. Beberapa postur yang extrim dan sering dilakukan oleh tenaga mekanik akan dianalisis untuk mengetahu tingkat resikonya. Hasil analisis akan memberikan petunjuk sehingga dapat diberikan usulan perbaikan postur kerja yang lebih aman. Tambahan informasi keluhan otot rangka yang diperoleh dari kuisioner Nordic Body Map dan hasil wawancara dengan para tenaga mekanik menjadi dasar untuk merancang alat bantu kerja yang ergonomis. Secara singkat dapat dikatakan bahwa kegiatan mencapai tujuan yang terbaik maka diperlukan metode terbaik, tempat terbaik dan waktu terbaik.

Penelitian ini akan melibatkan beberapa tenaga mekanik servise motor di bengkel yang telah dipilih sebagai tempat penelitian. Analisis di lakukan menggunakan Metode REBA, dengan mengukur berbagai postur kerja tenaga mekanik, terutama analisis postur kerja yang tidak ergonomis, dan merancang alat bantu yang ergonomis pada bengkel servis motor. Memahami penyebab keluhan biomekaniknya merupakan data penting sebagai bahan pertimbangan mendasar dalam membuat usulan rancangan alat bantu yang ergonomis. Melalui rancangan alat bantu kerja yang ergonomis diharapkan dapat memperbaiki postur kerja tenaga mekanik sekaligus mengurangi keluhan tenagan mekanik dalam melaksanakan pekerjaannya. Penelitian sebelumnya menggunakan pendekatan ergonomi menggunakan Metode REBA adalah untuk perancangan ulang Extrusion Torque 
untuk instalasi panel kaca [5], perancangan alat bantu packaging pada proses pengepakan produk Container Dry II [6], dan analisis Beban Kerja pada Pekerja Proses Pembuatan Dimsum [7].

\section{METODE PENELITIAN}

Penelitian perancangan alat bantu kerja berdasarkan analisis ergonomi postur kerja dan keluhan biomekanik tenaga mekanik motor di sebuah bengkel motor di Tangerang dilakukan dalam beberapa tahapan dimulai dari tinjauan ke bengkel motor yang dipilih, pemilihan responden dan persiapan alat ukur. Untuk mendapatkan permasalahan di bengkel maka dilakukan beberapa tahapan pengumpulan data. Langkah pertama yaitu memberikan kuisioner keluhan biomekanik kepada para montir sebelum bekerja dan sesudah bekerja. Adanya kondisi yang tidak ergonomis di stasiun kerja dapat diukur dengan menggunakan kuisioner Nordic Body Map (NBM). Wawancara dan mengisi kuisioner Nordic Body Map NBM adalah salah satu cara untuk mengenali sumber penyebab untuk melakukan evaluasi ergonomi, pengamatan dan dokumentasi tahapan kerja kegiatan servise motor. Kuesioner Nordic Body Map digunakan untuk mengetahui bagianbagian otot tubuh yang mengalami keluhan mulai dari rasa tidak nyaman (agak sakit) sampai sangat sakit [8]. Selain NBM, alat ukur lain yang digunakan untuk menilai risiko ergonomi pekerja yaitu Rapid Entire Body Assement (REBA). REBA adalah sebuah metode yang dikembangkan dalam bidang ergonomi dan digunakan secara cepat untuk menilai posisi kerja atau postur leher, punggung, lengan pergelangan tangan dan kaki seorang operator [9]. Metode ini juga dipengaruhi faktor coupling, beban eksternal yang ditopang oleh tubuh serta aktifitas pekerja [10]. Analisis REBA digunakan untuk memperkirakan besarnya risiko postur kerja para mekanik motorPerhitungan skor REBA postur kerja, analisa keluhan dan harapan, perancangan alat bantu kerja. Sedangkan batasan penelitian antara lain yaitu tidak membahas kekuatan bahan dan aspek keuangan. Berdasarkan data keluhan dan harapan konsumen serta data alat bantu yang ada di pasaran serta berdasarkan pertimbangan aspek ergonomi dilakukan perancangan alat bantu kerja baru yang ergonomis.

\section{HASIL DAN PEMBAHASAN}

Berdasarkan pengamatan di beberapa bengkel motor di daerah Tangerang diketahui bahwa pekerjaan di bengkel motor merupakan salah satu pekerjaan yang mengandalkan peran tenaga mekanik ketimbang tenaga mesin otomatis. Pekerjaan tenaga mekanik termasuk pekerjaan yang didominasi oleh pekerjaan fisik karena memerlukan pengerahan tenaga fisik yang cukup besar. Oleh karenanya mereka berisiko mengalami keluhan otot rangka dan dapat diperparah apabila postur kerja tenaga mekanik tidak ergonomis. Hasil dari kunjungan dan pengamatan terhadap beberapa bengkel motor diketahui bahwa mereka tidak memiliki sarana yang lengkap dalam upaya menangani berbagai pekerjaan perbaikan maupun penggantian komponen motor. Semua motor dan hampir semua jenis penanganan motor ditangani di atas lantai bengkel dengan sarana minimal dan tenaga mekanik terpaksa menngambil sikap tidak ergonomis. Di bengkel umum yang beroperasi di pinggir jalan biasanya melayani berbagai penggantian suku cadang maupun perbaikan kecil atau pun besar. Setidaknya terdapat 20 poin yang harus dilakukan oleh seorang mekanik untuk servis rutin [11].

Sejumlah 18 (delapan belas) tenaga mekanik diminta keterangannya untuk keperluan mencari solusi. Para montir memiliki masa kerja antara 1 tahun sd 22 tahun. Rata-rata masa kerja 18 tahun. Analisis keluhan fisik dapat memberitahukan apa yang menjadi penyebab keluhan yang dialami oleh tenaga mekanik motor. Di samping keluhan fisik, data postur kerja selama bekerja juga diolah untuk mendapatkan akar permasalahan. 


\section{Wayan Sukania}

Pengabungan antara data keluhan biomekanik dan analisis penyebabnya, data postur kerja data harapan tenaga mekanik merupakan sumber data untuk bahan perancangan fasilitas kerja. Adapun keluhan biomekanik paling banyak terjadi pada pinggang diikuti dengan keluhan pada bokong, leher bawah dan lutut.

Dari pengamatan sebagian besar pekerjaan tenaga mekanik motor dilakukan dengan postur berdiri dan jongkok. Untuk penanganan motor bagian bawah dilakukan postur jongkok atau duduk dengan alas duduk rendah sedangkan penanganan motor bagian atas dilakukan posisi berdiri. Punggung montir mengalami keluhan karena posisi duduk yang tidak nyaman (terlalu rendah). Postur jongkok dalam waktu lama akan mengakibatkan keluhan di beberapa bagian tubuh terutama pinggang. Postur berdiri membungkuk dan menjangkau serta memutar badan saat menangani perbaikan motor merupakan sebab utama keluhan pada pinggang. Karena penyebab utamanya tiadanya alat untuk meninggikan posisi motor, maka keluhan biomekanik cukup merata dialami oleh montir di berbagai bagian tubuhnya. Berikut ringkasan data kuisioner ditayangkan pada Tabel 1.

Tabel 1. Ringkasan Data Kuisioner Nordic Body Map

\begin{tabular}{|c|c|c|c|}
\hline \multirow{2}{*}{ No. } & \multirow{2}{*}{ Keluhan Yang Dialami } & \multicolumn{2}{|c|}{ Jawaban Ya } \\
\hline & & Sebelum Bekeja & Sesudah Bekerja \\
\hline 1 & Sakit Pada Leher Bagian Atas & 2 & 8 \\
\hline 2 & Sakit Pada Leher Bagian Bawah & 6 & 14 \\
\hline 3 & Sakit Pada Bahu Kiri & 1 & 11 \\
\hline 4 & Sakit Pada Bahu Kanan & 4 & 12 \\
\hline 5 & Sakit Pada Bagian Lengan Atas Bagian Kiri & 1 & 3 \\
\hline 6 & Sakit Pada Bagian Punggung & 1 & 8 \\
\hline 7 & Sakit Pada Bagian Lengan Atas Bagian Kanan & 2 & 5 \\
\hline 8 & Sakit Pada Pinggang & 6 & 16 \\
\hline 9 & Sakit Pada Bokong & 6 & 14 \\
\hline 10 & Sakit Pada Pantat & 2 & 6 \\
\hline 11 & Sakit Pada Siku Kiri & 1 & 3 \\
\hline 12 & Sakit Pada Siku Kanan & - & 3 \\
\hline 13 & Sakit Pada Lengan Bawah Bagian Kiri & - & 1 \\
\hline 14 & Sakit Pada Lengan Bawah Bagian Kanan & - & 6 \\
\hline 15 & Sakit Pada Pergelangan Tangan Kiri & - & 7 \\
\hline 16 & Sakit Pada Pergelangan Tangan Kanan & - & 9 \\
\hline 17 & Sakit Pada Tangan Bagian Kiri & - & 4 \\
\hline 18 & Sakit Pada Tangan Bagian Kanan & - & 4 \\
\hline 19 & Sakit Pada Paha Kiri & 2 & 10 \\
\hline 20 & Sakit Pada Paha Kanan & 3 & 11 \\
\hline 21 & Sakit Pada Lutut Kiri & - & 11 \\
\hline 22 & Sakit Pada Lutut Kanan & - & 13 \\
\hline 23 & Sakit Pada Betis Kiri & 2 & 4 \\
\hline 24 & Sakit Pada Betis Kanan & 6 & 5 \\
\hline 25 & Sakit Pada Pergelangan Kaki Kiri & 4 & 7 \\
\hline 26 & Sakit Pada Pergelangan Kaki Kanan & 6 & 7 \\
\hline 27 & Sakit Pada Kaki Kiri & - & 6 \\
\hline 28 & Sakit Pada Kaki Kanan & - & 6 \\
\hline
\end{tabular}

\section{Analisis REBA Beberapa Postur Kerja Tenaga Mekanik}

Mengingat banyaknya postur kerja dan bervariasinya kegiatan servise motor, berat ringannya kerusakan atau penggantian komponen serta tergantung pada tipe motor, maka dipilih beberapa postur yang cukup ekstrim dan sering dilakukan oleh tenaga mekanik motor. Berdasarkan analisis REBA diketahui beberapa postur tersebut ekstrim dan memerlukan perbaikan dengan segera. Penggabungan analisis keluhan, penyebab, harapan dan solusi diharapkan dapat dihasilkan konsep rancangan alat bantu kerja yang meminimalkan risiko keluhan biomekanik. Bebeberapa postur ekstrim teramati selama penelitian dimuat pada Gambar 1. Sedangkan perhitungan skor REBA ditayangkan pada 
Gambar 2. Berdasarkan analisis REBA diketahui beberapa postur tersebut extrim dan memerlukan perbaikan dengan segera. Postur tersebut misalnya saat membuka baut pembuangan oli dan penanganan bagian motor sebelah bawah menghasilkan risiko yang tinggi yaitu skor 11 dan 12 sehingga postur kerja sangat perlu diperbaiki.
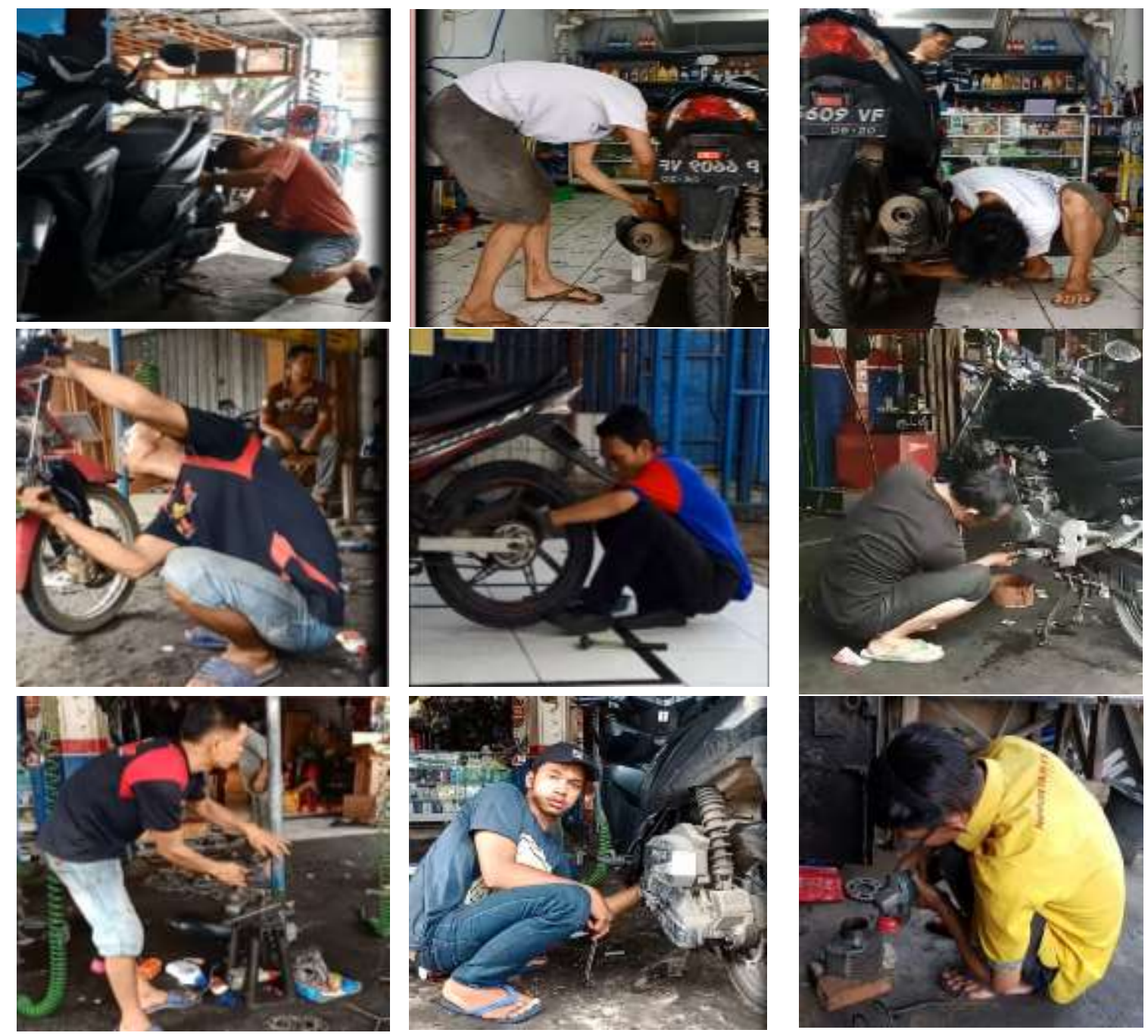

Gambar 1. Berbagai Postur Kerja Para Mekanik Sepeda Motor

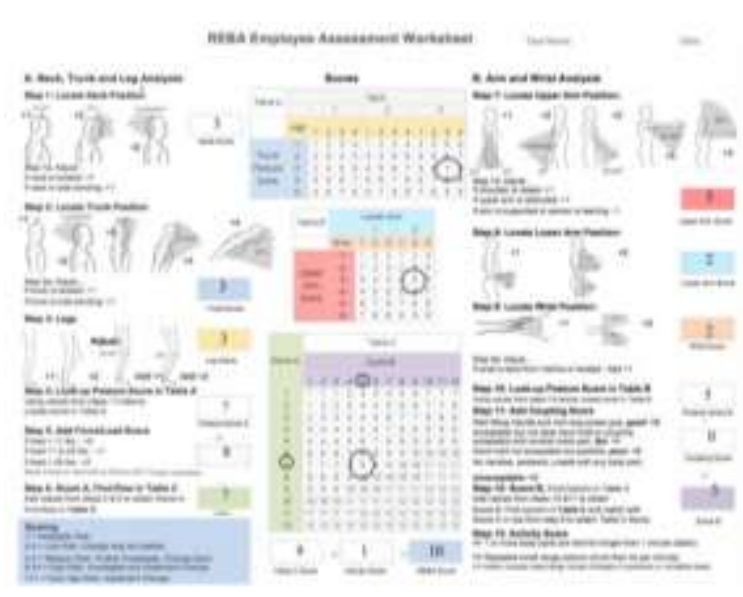

Andisis Resa Membua Sekrup

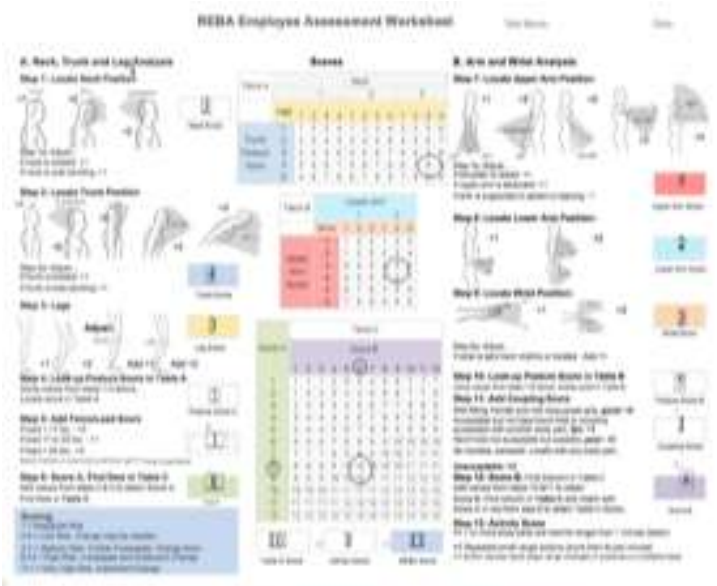

Araisis RezA Membuka Baut Pembuangan Oil

Gambar 2. Skor REBA Berbagai Postur Kerja Para Mekanik Sepeda Motor 


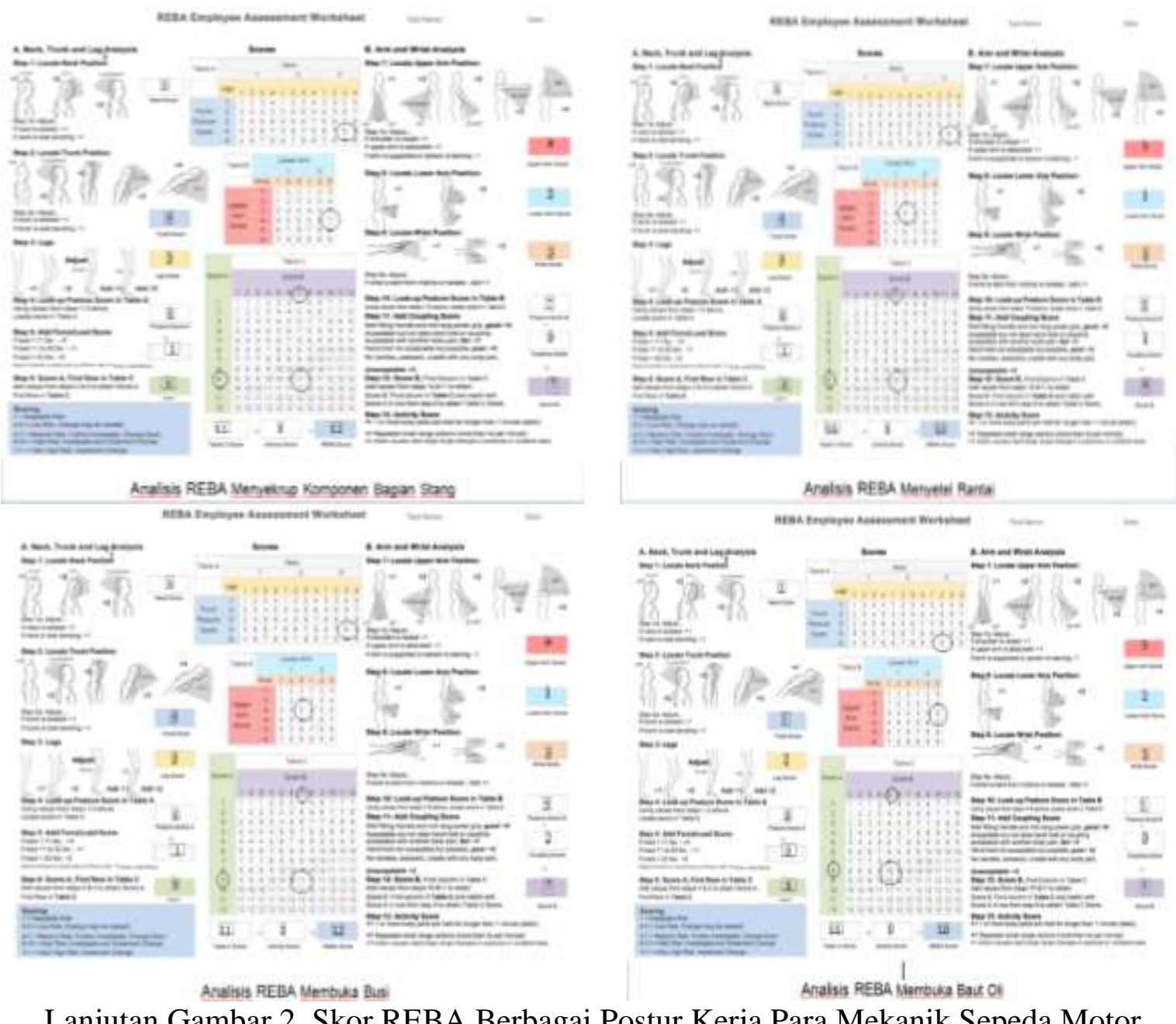

Lanjutan Gambar 2. Skor REBA Berbagai Postur Kerja Para Mekanik Sepeda Motor

\section{Analisis Keluhan, Harapan dan Solusi}

Keluhan biomekanik yang dirasakan oleh tenaga mekanik motor setelah melaksanakan tugas selama periode tertentu dapat diakibatkan oleh beberapa hal. Dalam bekerja, sikap tubuh sangat dipengaruhi oleh bentuk, susunan, ukuran dan tata letak peralatan seperti macam gerak, arah dan kekuatan. Kuesioner Nordic Body Map adalah kuesioner yang paling sering digunakan untuk mengetahui ketidaknyamanan pada para pekerja, dan kuesioner ini paling sering digunakan karena sudah terstandarisasi dan tersusun rapi.

Umumnya tenaga mekanik bertugas selama 8 jam sehari mulai pukul 08.00 pagi sampai pukul 17.00 sore. Besarnya keluhan bergantung pada berbagai hal, misalnya durasi pekerjaan, lamanya waktu istirahat, postur-postur selama bekerja, mudah tidaknya pekerjaan, tersedia tidaknya alat bantu serta kesadaran tenaga mekanik untuk bekerja secara benar, aman dan nyaman. Keluhan dan risiko postur kerja berdasarkan analisis REBA juga merupakan sumber informasi yang sangat penting dalam mengungkat kebutuhan tenaga mekanik saat ini. Beberapa solusi yang diperoleh setelah mengetahui penyebab keluhan antara lain:

a. Perancangan alat bantu tempat meletakkan motor yang dapat diatur ketinggiannya dengan mudah. Dimensi alat bantu sesuai dengan anthropometri pengguna sehingga pengguna tidak perlu membungkuk dan mengambil postur tidak ergonomis saat memperbaiki motor. 
b. Diperlukan alat bantu kerja untuk menempatkan motor pada posisi ketinggian yang tepat serta orientasi motor dapat diatur. Dengan demikian postur kerja alamiah berdiri tegak dan duduk sempurna dapat dicapai. Alat bantu dengan dengan dimensi dan fungsi yang tepat sehingga dapat menghemat tenaga dan frekuensi gerakan kerja montir.

\section{Perancangan Alat Bantu Kerja.}

Dengan menggabungkan berbagai fakta selanjutnya dianalisis untuk mendapatkan solusi. Penggabungan analisis keluhan, penyebab dan harapan menghasilkan solusi berupa perancangan alat bantu yang ergonomis yang meminimalkan postur ekstrim, meminimalkan pengerahan tenaga mekanik saat bertugas. Solusi juga ditanyakan secara langsung kepada semua montir sehingga masing-masing memberikan pendapatnya. Solusi yang diperoleh adalah perancangan alat bantu tempat meletakkan motor yang dapat diatur ketinggiannya dengan mudah. Dimensi alat bantu sesuai dengan anthropometri pengguna sehingga pengguna tidak perlu membungkuk dalam melakukan pekerjaannnya.

Perancangan alat bantu kerja untuk meningkatkan kenyamanan kerja para tenaga mekanik motor dilakukan melalui beberapa tahapan [12]. Berdasarkan data pada keluhan, harapan dan solusi selanjutnya dibuat rincian interpretasi kebutuhan konsumen (tenaga mekanik). Interpretasi kebutuhan konsumen merupakan bagian penting dari fase pengembangan konsep yang merupakan salah satu fase pada proses pengembangan produk. Tahapan ini menjamin bahwa produk telah difokuskan terhadap kebutuhan pelanggan dan tidak ada kebutuhan penting yang terlewatkan. Kebutuhan pelanggan diperoleh dengan wawancara, memperhatikan saat konsumen menggunakan produk, keluhan biomekanik konsumen untuk memperkirakan kebutuhan dan harapan konsumen. Berdasarkan wawancara, kuisioner Nordic body map dan analisa kebutuhan konsumen, maka diperoleh daftar kebutuhan konsumen.

Identifikasi kebutuhan bertujuan untuk mengetahui kebutuhan konsumen dan hal-hal yang harus dilakukan dalam merancang produk. Selanjutnya dibuat tingkat kepentingan kebutuhan konsumen. Kebutuhan juga didasarkan atas pertimbangan perancang dan produk sejenis yang ada saat ini. Beberapa kebutuhan yang mirip dijadikan satu pernyataan kebutuhan. Nilai kepentingan 5 artinya paling penting. Nilai kepentingan 0 artinya tidak penting.

Setelah kebutuhan konsumen ditetapkan, langkah selanjutnya yaitu menetapkan spesifikasi teknis untuk memenuhi kebutuhan tersebut. Idealnya satu kebutuhan diwakili oleh satu metric atau ukuran. Namun pada faktanya beberapa kebutuhan dapat diwakili oleh satu metric.

Langkah selanjutnya adalah membuat konsep produk yang mampu melaksanakan fungsi seperti kebutuhan konsumen. Pohon Klasifikasi konsep digunakan untuk memisahkan keseluruhan penyelesaian yang mungkin menjadi beberapa kelas berbeda yang akan memudahkan perbandingan dan pemangkasan. Empat parameter penting yaitu disain alas tempat meletakkan motor, mekanisme penggerak rangka, tenaga penggerak dan tempat meletakkan tools. Selanjutnya diperoleh 4 konsep untuk dipertimbangkan. Setelah melewati tahapan penyaringan konsep dan penilaian konsep diputuskan konsep terpilih yaitu konsep A yaitu alat angkat motor dengan disain alas tempat meletakkan motor bidang persegi panjang. Konstruksi rangka penggerak berupa rangka silang. Sedangkan tenaga penggerak menggunakan motor listrik yang menggerakkan poros berulir dan mekanisme reduksi putaran. Untuk tempat meletakkan peralaan kerja menggunakan bidang datar. Berikut Gambar 3 menyajikan pohon solusi. 


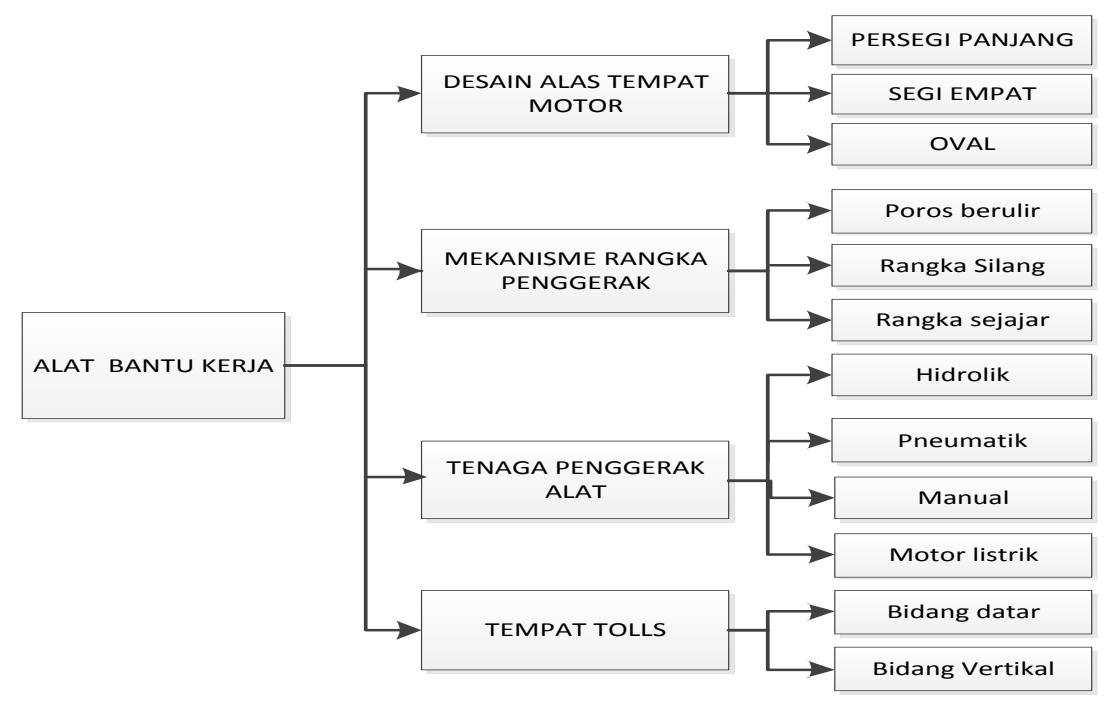

Gambar 3. Pohon Klasifikasi Konsep Alat Bantu Kerja Mekanik Motor

Berdasarkan beberapa pertimbangan seperti faktor data anthropometri, kesederhaan rangka dan pertimbangan produk pesaing, maka ditetapkan spessifikasi alat bantu angkat motor tersebut. Penyusunan spesifikasi, pembuatan konsep, pemilihan konsep dan penentuan spesifikasi akhir. Adapun spesifikasi akhir yaitu:

a. Panjang alas meletakkan motor $1850 \mathrm{~mm}$. Montir selama mengerjakan motor biasanya berpindah tempat sehingga anthropometri jangkauan tangan ke samping (Jarak bentang tangan kiri dan kanan pada persentil ke 5 pria yaitu $1.520 \mathrm{~mm}$ ) tidak terlalu mengikat.

b. Lebar alas atau bad tempat meletakkan motor dengan lebar $700 \mathrm{~mm}$ dengan pertimbangan keamanan motor agar berada di dalam area meja alat angkat. Lebar ini juga sebagai pertimbangan tempat meletakkan peralatan kerja dan komponen motor. Tempat meletakkan alat alat kerja (kunci pas, obeng tank dll) tak perlu dibuat khusus. Lebar alas juga ditentukan oleh panjang jangkauan tangan ke depan yaitu $474 \mathrm{~mm}$ [13]. Biasanya untuk menangani motor para tenaga mekanik dapat mengambil posisi kanan dan kiri motor sesuai dengan komponen motor yang diperbaiki.

c. Jangkauan tinggi maksimal digunakan untuk memenuhi kebutuhan tenaga mekanik untuk memposisikan motor yang akan diservis., Dasar ukuran yang dipakai yaitu antrhopometri tinggi siku berdiri mekanik yang paling tinggi (Persentil ke 95). Berdasarkan tabel data anthropometri tinggi posisi siku persentil 95 pria adalah 1.074 $\mathrm{mm}$ [13]. Dengan mempertimbangkan berbagai sudut siku saat bekerja dan ketinggian standar ganda saat diparkir yaitu sekitar $20 \mathrm{~cm}$, maka diambil ketinggian maksimal alas $900 \mathrm{~cm}$. Untuk Merk Westco sebagai perbandingan tinggi maksimum $780 \mathrm{~cm}$ [14].

d. Untuk rangka dipilih model gunting atau X-bar atau scissors agar ketika alat dioperasikan langsung bergerak keatas sehingga menghemat pemakaian tempat. Rangka didorong oleh mekanisme poros berulir yang digerakkan oleh motor listrik yang sebelumnya putarannya direduksi oleh bgearbox. Rangka model ini diperkirakan sangat aman untuk berat motor matik sekitar $100 \mathrm{~kg}$, sedangkan untuk motor laki sekitar $125 \mathrm{~kg}$ [15].

e. Dimensi motor, dimensi balok rangka dll, tidak dihitung pada penelitian ini namun akan dilanjutkan pada penelitian selanjutnya.

f. Segala fasilitas dan alat control pada alat disediakan demi kemudahan para tenaga mekanik untuk menggunakan alat bantu angkat tersebut. 


\section{KESIMPULAN}

Data hasil pengamatan, pengolahan data dan perancangan alat bantu angkat motor menghasilkan kesimpulan bahwa keluhan biomekanik terbanyak terjadi pada bagian tubuh seperti pinggang, leher atas, lutut dan bahu kanan. Penyebab keluhan adalah postur yang tidak ergonomis. Skor Reba 12 terjadi pada postur membuka baut pembuangan oli. Berdasarkan data kebutuhan konsumen dan berbagai pertimbangan produk pesaing diperoleh sebuah konsep alat bantu angkat motor dengan disain alas tempat meletakkan motor bidang persegi panjang. Konstruksi rangka penggerak berupa rangka silang. Sedangkan tenaga penggerak menggunakan motor listrik yang menggerakkan poros berulir dan mekanisme reduksi putaran. Spesifikasi alat bantu angkat yaitu panjang alas meletakkan motor $1850 \mathrm{~mm}$. Lebar alas atau bad tempat meletakkan motor dengan lebar $700 \mathrm{~mm}$, ketinggian min $20 \mathrm{~cm}$ dan ketinggian maksimum $900 \mathrm{~cm}$. Alat menggunakan rangka silang, penggerak motor listrik melalui poros berulir.

\section{DAFTAR PUSTAKA}

[1] https://www.gridoto.com/read/221016518/prosedur-servis-ringan-motor-honda-dibengkel-resmi-ada-9-hal-yang-dicek-nih diakses tgl 10 Januari 2019.

[2] R.S Bridger, "Introduction to Ergonomic", Singapore: McGraw Hill Inc.1995

[3] I. Z. Sutalaksana, dkk," Teknik Perancangan Sistem Kerja edisi kedua", Bandung: Labolatorium Tata Cara Kerja \& Ergonomi, Departemen Teknik Industri ITB.2006.

[4] T. Mahardika, dan D. Pujotomo, "Perancangan Fasilitas Kerja Untuk Mengurangi Keluhan Musculoskeletal Disorders (MSDs) Dengan Metode Rapid Entire BodyAssesment Pada Pekerja Pembuatan Paving dan Batako pada UKM Usaha Baru", Jurnal TI Undip, Vol. IX, No. 2, Mei 2014.

[5] S. Ariyanti, dan K. Arifin, "Perancangan Ulang Extrusion Torque Untuk Instalasi Panel Kaca Dengan Pendekatan Ergonomi”, Jurnal Ilmiah Teknik Industri, vol.7 no.1, pp. 8-15, 2019.

[6] N. Azmi, I W Sukania, dan J Samsudin, "Analisis Beban Kerja Pada Pekerja Proses Pembuatan Dimsum,” Jurnal Ilmiah Teknik Industri, vol.4 no.3, pp.184-191, 2016.

[7] F.J. Daywin, J.N Samuel, C. O. Doaly, Ahmad, L. Gozali, I W. Sukania, "Kegiatan Pengabdian Masyarakat: Perancangan Alat Bantu Packaging Pada Quality Control Container Dry II PT. Clariant Adsorbent Indonesia", Prosiding SNMI XIII dan SNTKT IX, pp. 188-196, April 2019.

[8] Tarwaka, Solichul H.B dan Lilik, S, 2004. Ergonomi untuk Keselamatan Kerja dan Produktivitas. Surakarta: Uniba Press.

[9] Madani, Dima Al. dan Awwad Dababneh, "Rapid Entire Body Assessment: A Literature Review. American Journal of Engineering and Applied Sciences", The University of Jordan, Amman, Jordan, 2016.

[10] Hignett, S. and L. McAtamney, 2000. Rapid Entire Body Assessment (REBA). Applied Ergonom., 31: 201-205. DOI: 10.1016/S0003-6870(99)00039-3.

[11] https://otomania.gridoto.com/read/241169485/apa-yang-dilakukan-mekanik-saatservis-sepeda-motor, diakses tgl 11 September 2019.

[12] Ulrich. Eppinger, Perancangan dan Pengembangan Produk, diterjemahkan oleh Nora Azmi, Iveline Anne Marie, Salemba Teknika,Jakarta, 2001.

[13] Nurmianto, Ergonomi, Konsep Dasar dan Aplikasinya. PT. Guna Widya, Jakarta. 1998.

[14] https://www.tokopedia.com/wildhasonata/westco-bike-lift-alat-service-motor-alatangkat-motor. diakses tgl 15 Januari 2019.

[15] https://kangmase.wordpress.com/2011/06/03/gw250-berapa-sih-idealnya-berat-motor diakses tgl 11 Januari 2019. 